\title{
Elektroterapia, interwencje, leki... Migawki z Kongresu Europejskiego Towarzystwa Kardiologicznego w Barcelonie, 26-30 sierpnia 2017 roku
}

\author{
Electrotherapy, intervention, therapy... Snapshots from the Congress \\ of the European Society of Cardiology in Barcelona, August 26-30, 2017
}

\author{
Łukasz Figiel, Jarosław D. Kasprzak
}

Klinika Kardiologii Katedry Kardiologii Uniwersytetu Medycznego w Łodzi

\begin{abstract}
Słoneczna ziemia katalońska po raz kolejny gościła prawie 40-tysięczną rzeszę uczestników odbywającego się w Barcelonie od 26 do 30 sierpnia 2017 roku Europejskiego Kongresu Kardiologicznego (ESC, European Society of Cardiology) - najważniejszego w Europie (a być może i na całym świecie) wydarzenia dla wszystkich lekarzy zajmujących się szeroko pojętą diagnostyką i leczeniem chorób układu sercowo-naczyniowego. Jak zawsze spośród wielu różnych sesji tematycznych największym zainteresowaniem uczestników cieszyły się sesje hot line, na których prezentowano ( $\mathrm{i}$ "na gorąco" komentowano) wyniki najnowszych badań z dziedziny kardiologii klinicznej, a zwłaszcza zastosowania nowych leków i nowych technologii medycznych.

W tym roku program sesji hot line był wyjątkowo bogaty i dotyczył wielu aspektów diagnostyki i terapii, ale warto podkreślić, że niemała liczba badań klinicznych zakończyła się wynikami bądź neutralnymi, bądź nawet niekorzystnymi dla ocenianych nowych strategii. Wśród licznych prezentacji najnowszych badań klinicznych trudno było wyłowić doniesienia przełomowe, z potencjałem istotnej zmiany w dotychczasowych kanonach terapii - do niniejszego opracowania wybrano najciekawsze, w subiektywnej ocenie, poniższe badania związane z leczeniem zabiegowym w kardiologii - takie, które mogą stanowić praktyczne odwołania do codziennej pracy nowoczesnego klinicysty.

Jednym z najważniejszych wydarzeń pierwszego dnia kongresu była prezentacja ( $w$ ramach sesji „Hot Line-Late-Breaking Science in PCl") wyników badania SYNTAX II [1], dotyczącego porównania wyników rewaskularyzacji wieńcowej metodą chirurgiczną (CABG, coronary artery bypass grafting) i metodami przezskórnymi ( $\mathrm{PCl}$, percu-
\end{abstract}

taneous coronary intervention) z użyciem współczesnych stentów uwalniających leki (DES, drug-eluting stent). 0 ile we wcześniejszym badaniu SYNTAX I porównywano wyniki leczenia techniką CABG w chorobie wielonaczyniowej ze standardowym zabiegiem angioplastyki, o tyle w obecnym badaniu uwzględniono ogromny postęp w zakresie oceny istotności hemodynamicznej zmian w łożysku wieńcowym. W protokole zakładano leczenie wyłącznie istotnych czynnościowo zwężeń (bez stentowania zmian, które poddane badaniu czynnościowemu, jak np. badanie cząstkowej rezerwy przepływu [FFR, fractional flow reserve], przestawały być zmianami indukującymi istotne niedokrwienie) oraz kontrolę skuteczności procedury za pomocą ultrasonografii wewnątrzwieńcowej (IVUS, intravenous ultrasonography). W badaniu SYNTAX II, przy podejmowaniu decyzji przez heart team, uwzględniano zatem zarówno skalę SYNTAX, jak i wyniki badania czynnościowego (iFR [instantaneous wave-free ratio]/FFR), stenty DES II generacji oraz stentowanie pod kontrolą IVUS, czyli w proces decyzyjno-leczniczy wprzęgnięto całe nowoczesne armamentarium, jakim obecnie dysponuje kardiologia inwazyjna. Badanie było prospektywne, wieloośrodkowe (także przy współudziale ośrodków polskich) i obejmowało 450 osób z choroba wielonaczyniową (średnio 3,5 zmiany/pacjenta) bez zajęcia pnia lewej tętnicy wieńcowej, a grupę kontrolną stanowiło 315 pacjentów z kohorty pierwotnego badania SYNTAX. U chorych, których w wyniku konsultacji heart team kierowano na zabieg koronaroplastyki, w ponad $75 \%$ przypadków wykonywano fizjologiczną ocenę istotności zwężeń przy użyciu iFR (u 25\% nie wykonano badania czynnościowego, m.in. z powodu braku możliwości pasażu

Adres do korespondencji: dr n. med. Łukasz Figiel, Klinika Kardiologii, Katedra Kardiologii, Uniwersytet Medyczny w Łodzi, Wojewódzki Szpital Specjalistyczny im. W. Biegańskiego, ul. Kniaziewicza 1/5, 91-347 Łódź, e-mail: medluk@wp.pl 
prowadnika do pomiaru ciśnień na obwód naczynia). Oceniano 1150 zwężeń; w przypadku wyniku poniżej 0,86 (603 zwężenia) ad hoc wykonywano angioplastyke, w przypadku wartości zawartej w przedziale 0,860,93 (264 zwężenia) dodatkowo wykonywano pomiar FFR, co u prawie $70 \%$ osób z tej podgrupy prowadziło do koronaroplastyki, natomiast $\mathrm{w}$ przypadku wartości iFR powyżej 0,94 (283 zwężenia) zabieg odraczano. Tylko u kilkunastu pacjentów pierwotnie zamiast iFR wykonano badanie FFR. W ramach zabiegu PCI wszczepiano stenty Synergy $^{\mathrm{TM}}$ (pokrywane ewerolimusem), przy czym w ponad 80\% przypadków zabieg optymalizowano przy użyciu sondy IVUS. Co warte podkreślenia, w toku dalszej obserwacji bardzo restrykcyjnie, zgodnie z wytycznymi, kontrolowano lipidogram. Pierwotnym punktem końcowym była ocena częstości występowania poważnych zdarzeń sercowo-naczyniowych ([MACCE, major adverse cardiovascular and cerebrovascular events] zdefiniowanych jako zawał serca, udar mózgu, zgon z jakiejkolwiek przyczyny oraz konieczność rewaskularyzacji) w trwającej rok obserwacji. Po upływie tego okresu okazało się, że chorzy objęci strategią postępowania przezskórnego, w myśl założeń badania SYNTAX II, w porównaniu z grupą stentowaną „tradycyjnie" w badaniu SYNTAX, cechowali się istotnie statystycznie mniejszą liczbą poważnych powikłań krążeniowych $(10,6 \%$ v. 17,4\%; $p=0,006)$. Zmniejszeniu uległy częstość zawału serca (1,4\% v. 4,8\%; $p=0,007)$, powtórnej rewaskularyzacji $(8,2 \%$ v. 13,7\%; $p=0,015)$ i zakrzepicy w stencie $(0,7 \%$ v. $2,7 \% ; p=0,045)$. Różnice pod względem śmiertelności całkowitej i częstości udarów nie osiągnęły istotności statystycznej. Dodatkowo badacze porównali tę grupę chorych z kohortą 334 pacjentów z badania SYNTAX poddanych CABG. W trakcie trwającej rok obserwacji częstość MACCE u chorych z badania SYNTAX II była porównywalna $(10,6 \%$ v. 11,2\%; $p=0,68)$ z obserwowaną u pacjentów z grupy poddanej CABG. Wyniki badania SYNTAX II dobitnie więc wykazują, że w chorobie wielonaczyniowej precyzyjna ocena istotności hemodynamicznej zwężeń jest niezmiernie istotna i wraz z optymalną techniką zabiegu AD 2017 przekłada się na obniżenie ryzyka poważnych zdarzeń sercowych i powinna zostać szeroko zaimplementowana w tej grupie pacjentów. Silną stroną chirurgicznej rewaskularyzacji pozostaje zmniejszona częstość ponownej rewaskularyzacji.

Kolejnym interesującym badaniem, którego wyniki przedstawiono na pierwszej sesji porannej „Hot Line-Late-Breaking Clinical Trials” i które może istotnie wpłynąć na leczenie chorych z niewydolnością serca i współistniejącym migotaniem przedsionków (AF, atrial fibrillation) było badanie CASTLE-AF (Catheter ablation versus standard conventional treatment in patients with left ventricular dysfunction and atrial fibrillation) [2]. Niewydolność serca często współistnieje z AF, zatem za celowe uznano sprawdzenie w warunkach kontrolowanej próby klinicznej, czy u takich pacjentów przezcewnikowa ablacja AF zmniejsza śmiertelność lub tempo progresji niewydolności serca w porównaniu z konwencjonalną terapią farmakologiczną.

Badanie CASTLE-AF to największa na świecie randomizowana próba kliniczna poświęcona skuteczności ablacji cewnikowej AF u pacjentów z niewydolnością serca. Wzięło w nim udział 397 pacjentów z wszczepionym kardiowerterem-defibrylatorem (ICD, implantable cardioverter-defibrillator) lub urządzeniem do terapii resynchronizującej z funkcja defibrylacji (CRT-D, cardiac resynchronization therapy with defibrillator), włączanych w 33 ośrodkach w Europie, Australii i Stanach Zjednoczonych w latach 2008-2016. Jest to zarazem pierwsze badanie metody ablacji cewnikowej AF służące zbadaniu występowania pierwotnego złożonego, istotnego klinicznie punktu końcowego - śmiertelności i chorobowości związanej z niewydolnością serca przy średniej obserwacji trwającej ponad 3 lata. Do badania włączono 397 pacjentów z objawowym, napadowym lub przetrwałym AF, frakcją wyrzutową lewej komory nie większą niż 35\%, w Il lub wyższej klasie czynnościowej według New York Heart Association (NYHA) oraz z implantowanym urządzeniem (CRT-D/ICD) w ramach prewencji pierwotnej lub wtórnej nagłego zgonu sercowego. Po wstępnym okresie 5 tygodni leczenia/obserwacji chorzy byli losowo przydzielani do grupy poddanej „konwencjonalnej” farmakoterapii (184 pacjentów) albo do grupy podlegającej procedurze ablacji AF (179 pacjentów). Pacjentów z grupy postępowania zachowawczego leczono zgodnie ze standardami ESC/AHA dotyczącymi odpowiedniej antykoagulacji z wartością międzynarodowego współczynnika znormalizowanego (INR, international normalized ratio) w zakresie 2,0-3,0, strategii kontroli rytmu lub kontroli rytmu komór. Obie grupy nie różniły się pod względem głównych parametrów, takich jak wiek, klasa według NYHA, stopień dysfunkcji lewej komory czy proporcje występowania napadowego lub przetrwałego AF. Obie grupy objęto podobnym leczeniem farmakologicznym, przy czym pacjenci w grupie poddawanej ablacji nieco częściej (97\% vs. $85 \%$ ) przyjmowali amiodaron. Protokół zabiegu ablacji przezcewnikowej obejmował pełną izolację żył płucnych (z ewentualnym powtórnym zabiegiem po okresie „blankingu"). Zgodnie z przewidywaniami ablacja w porównaniu z terapią konwencjonalną skutkowała prawie o połowę mniejszą częstością nawrotów AF mierzonych jako napady szybkich rytmów nadkomorowych rejestrowane w pamięci urządzeń wszczepialnych. Zarówno po 12 miesiącach, jak i na koniec badania (czyli po 60 miesiącach) w grupie poddanej ablacji, w porównaniu z chorymi poddanymi optymalnej terapii farmakologicznej, istotnie statystycznie zwiększała się frakcja wyrzutowa lewej komory - odpowiednio o 7\% w porównaniu z 2\% ( $p=0,001)$ w obserwacji rocznej i 8\% w porównaniu z 0\% w obserwacji 5-letniej ( $p=$ $=0,005)$. Co zrozumiałe, w grupie poddanej ablacji przezcewnikowej istotnie częściej pojawiały się zależne od przebiegu 
zabiegu powikłania, takie jak płyn w worku osierdziowym $(1,7 \%$ v. $0 \%)$ czy ciężkie krwawienia (1,7\% v. 0\%), ale ablacja lepiej chroniła przed incydentami udarów mózgu czy przejściowych napadów niedokrwiennych (TIA, transient ischemic attack) (3,9\% v. 6,7\%). Jednak najważniejszym wynikiem badania był fakt, że pierwotny złożony punkt końcowy w trakcie 60 miesięcy obserwacji znamiennie rzadziej występował w grupie chorych leczonych ablacją przezcewnikową; osiągnięto zmniejszenie o 38\% liczby zgonów i hospitalizacji spowodowanych zaostrzeniem niewydolności serca w porównaniu z terapią farmakologiczną zalecaną w aktualnych wytycznych ( $p=0,007)$. Również, począwszy od 3. roku obserwacji, wykazano, że całkowita śmiertelność była znamiennie niższa w grupie pacjentów leczonych zabiegowo - uzyskano 47-procentowe obniżenie ryzyka ( $p=0,011)$. Ten sam efekt dotyczył śmiertelności z przyczyn sercowo-naczyniowych (zmniejszenie ryzyka o 51\%; $p=0,008$ ) oraz pogorszenia niewydolności serca (redukcja ryzyka o 44\%; $p=0,004$ ). W sposób niebudzący wątpliwości wykazano zatem w tym badaniu po raz pierwszy bardzo pozytywny wpływ zabiegu ablacji AF na zmniejszenie ryzyka występowania „twardych” punktów końcowych u chorych z niewydolnością serca i współistniejącą arytmią. Mimo ograniczonej liczebności grupy trzeba podkreślić długi okres obserwacji i spójność uzyskanych wyników. Należy oczekiwać, że rezultaty tej próby klinicznej wpłyną na kształt przyszłych wytycznych dotyczących niewydolności serca ze współistniejącą arytmią. W świetle wyników CASTLE-AF można zakładać, że procedura ablacji AF powinna być wykonywana jak najszybciej jako terapia pierwszego rzutu w grupie pacjentów z niewydolnością serca i obniżoną frakcją wyrzutową.

Migotanie przedsionków stanowi typowy czynnik komplikujący wykonanie typowych zabiegów terapeutycznych ze względu na konieczność adekwatnej antykoagulacji, co może powodować zwiększenie częstości powikłań krwotocznych lub zatorowych. W badaniu EMANATE (Eliquis evaluated in acute cardioversion coMpared to usuAl treatmeNts for AnTicoagulation in subjects with NVAF) [3] wykazano, że apiksaban jest dobrą alternatywą dla heparyny i antywitamin K u pacjentów przygotowywanych do kardiowersji elektrycznej po krótkotrwałym (< 48 h) incydencie arytmii, bez uprzedniej przewlekłej doustnej antykoagulacji. Oceniano typowe dawki apiksabanu ( $2 \times 2,5-2 \times 5 \mathrm{mg})$ z możliwością wykorzystania dawki ładującej - jednorazowo $10 \mathrm{mg}$ (lub, okazjonalnie, $5 \mathrm{mg}$ przy typowych wskazaniach do zmniejszenia dawkowania). W badanej kohorcie 1500 osób leczenie apiksabanem wiązało się z nieobecnością powikłań zatorowych ( 0 v. 0,8\% w grupie kontrolnej - heparyna/antywitaminy K, znamienna różnica; $p=0,016)$. U pacjentów, u których przed kardiowersją przeprowadzono przezprzełykową echokardiografię, częstość skrzeplin była podobna w obu ramionach, podobnie jak szansa ich rozpuszczenia po
5 tygodniach (nieco > 50\%). Mimo niedostatecznej mocy statystycznej, typowej dla badań nad zatorowością po kardiowersji, pozytywne wyniki zachęcają do stosowania apiksabanu w scenariuszu przygotowania do kardiowersji pacjentów wcześniej nieantykoagulowanych.

Inny typowy problem to wykonanie $\mathrm{PCl}$ u pacjenta wymagającego przewlekłej antykoagulacji. W badaniu RE-DUAL [4] oceniano, czy protokół leczenia oparty na dabigatranie z lekiem przeciwpłytkowym okaże się równie bezpieczny i skuteczny, jak standardowa potrójna terapia z wykorzystaniem antywitaminy $\mathrm{K}$ i dwóch leków przeciwpłytkowych. Grupę 2725 badanych pacjentów leczonych $\mathrm{PCl}$ z dowolnych wskazań przydzielano losowo do trzech strategii, tj. trwającego rok 1) leczenia warfaryną oraz leczenia przeciwpłytkowego (przez 1-3 miesiące kwas acetylosalicylowy + klopidogrel lub tikagrelor przez rok), 2) leczenia dabigatranem w dawce 2 razy $110 \mathrm{mg}$ wraz z klopidogrelem w dawce $75 \mathrm{mg} /$ dobę lub tikagrelorem w dawce 2 razy $90 \mathrm{mg}$ albo 3) leczenia dabigatranem w dawce 2 razy $150 \mathrm{mg}$ wraz z klopidogrelem w dawce $75 \mathrm{mg} /$ dobę lub tikagrelorem w dawce 2 razy $90 \mathrm{mg}$. Obserwacja roczna była skupiona na ryzyku krwawień i na ryzyku powikłań zakrzepowych. Wykazano znaczącą przewage terapii opartej na dabigatranie - istotne krwawienia były o 48\% rzadsze niż w grupie przyjmującej warfarynę w przypadku dawki $110 \mathrm{mg}$ (26,9\% v. 15,4\%; $\mathrm{p}<0,001)$; dabigatran w dawce 2 razy $150 \mathrm{mg}$ spowodował krwawienia u 20,2\% badanych. Nie stwierdzono natomiast obniżenia skuteczności przeciwzakrzepowej w grupach leczonych dabigatranem oraz warfaryną z podwójną terapią przeciwpłytkową (DAPT, dual anti-platelet therapy) - częstość punktu końcowego ukierunkowanego na skuteczność leczenia (złożonego z oceny liczby zgonów, zawałów serca, udarów mózgu, zatorowości i nieplanowanych rewaskularyzacji) była niemal identyczna i wynosiła odpowiednio 13,4\% i 13,7\%. Wyniki badania pozwalają jednoznacznie wskazać strategię leczenia pacjentów poddawanych PCl i wymagających profilaktyki zakrzepicy opartą na dabigatranie i klopidogrelu (lub zastosowanym u $12 \%$ chorych tikagrelorze) jako bezpieczniejszą alternatywę dla postępowania standardowego opartego na antywitaminie $\mathrm{K}$.

Ostatnie omawiane badanie, SPYRAL HTN-OFF MED (Investigation of catheter-based renal denervation in patients with uncontrolled hypertension in the absence of antihypertensive medications) [5], dotyczyło zastosowania denerwacji tętnic nerkowych w leczeniu nadciśnienia tętniczego. Wydawało się, że po rozczarowujących wynikach badania SYMPLICITY HTN-3 koncepcja przeznaczyniowego odnerwiania tętnic nerkowych w celu obniżania ciśnienia tętniczego całkowicie upadła, jednak wciąż podejmuje się próby udowodnienia korzystnego wpływu hipotensyjnego tej procedury, wykonywanej z użyciem udoskonalonego sprzętu. Badanie SPYRAL-HTN zaplanowano, 
by zbadać wpływ denerwacji na niekontrolowane ciśnienie tętnicze. Była to wieloośrodkowa, randomizowana próba kliniczna o typie sham-control (tzn. w podgrupie chorych niepoddanych denerwacji również wprowadzano do tętnic nerkowych cewnik wieloelektrodowy, ale nie wykonywano ablacji) przeprowadzona w 21 ośrodkach na całym świecie. Kryteriami włączenia do badania były nadciśnienie tętnicze definiowane jako gabinetowe wartości ciśnienia skurczowego 150 mm Hg lub wyższe, ale niższe od 180 mm Hg oraz wartości ciśnienia rozkurczowego $90 \mathrm{~mm} \mathrm{Hg} \mathrm{lub} \mathrm{większe,}$ jak również wartości ciśnienia skurczowego w 24-godzinnym monitorowaniu $140 \mathrm{~mm}$ Hg lub wyższe, ale niższe od 170 mm Hg u pacjentów, którzy albo nie przyjmowali jeszcze w ogóle leków przeciwnadciśnieniowych albo czasowo zaprzestali ich stosowania. Do głównych kryteriów wykluczenia należały niekorzystna anatomia tętnic nerkowych, szacowany wskaźnik przesączania kłębuszkowego (eGFR, estimated glomerular filtration rate) poniżej $45 \mathrm{ml}$ /min/1,73 m², cukrzyca typu 1 lub źle kontrolowana cukrzyca typu 2 oraz nadciśnienie wtórne. Do badania włączono 353 pacjentów; z tej liczby prawie 260 chorych wyłączono w trakcie dwóch pierwszych wizyt przesiewowych, głównie z powodu niezgodnych z protokołem wartości ciśnienia tętniczego (w pomiarach w trakcie wizyty lub w ambulatoryjnym monitorowaniu ciśnienia tętniczego [ABPM, ambulatory blood pressure monitoring]). Ostatecznie spośród 80 chorych 38 przydzielono do grupy denerwacji, a 42 - do grupy kontrolnej. Wszystkich pacjentów w sedacji poddano angiografii tętnic nerkowych, a pacjentów z grupy denerwacji - ablacji przy użyciu nowej generacji systemu, jakim był czteroelektrodowy cewnik o średnicy 6F, z 60-sekundowymi aplikacjami prądu o częstotliwości radiowej. Po 3-miesięcznej obserwacji obu grup chorych średnie ciśnienie skurczowe (mierzone w ABPM) w grupie poddanej denerwacji obniżyło się o $5,5 \mathrm{~mm} \mathrm{Hg}$, zaś w grupie kontrolnej - o 0,5 mm Hg (znamienna różnica; $p=0,04)$, a średnie ciśnienie rozkurczowe w grupie badanej obniżyło się o 4,8 mm Hg w porównaniu z obniżeniem o 0,4 mm Hg w grupie kontrolnej ( $p=0,002)$. Podobne znamienne efekty denerwacji udokumentowano w trakcie wizyty kontrolnej - w grupie poddanej denerwacji ciśnienie skurczowe obniżyło się o $10 \mathrm{~mm} \mathrm{Hg}$, zaś w grupie kontrolnej o 2,3 mm Hg (znamienne obniżenie o 7,7 mm Hg; $p=0,02)$; średnie ciśnienie rozkurczowe $w$ grupie badanej obniżyło się o 5,3 mm Hg w porównaniu z 0,3 mm Hg w grupie kontrolnej ( $p=0,008)$. Procedura ablacji była bardzo bezpieczna, gdyż zabiegi wykonywali wyselekcjonowani, bardzo doświadczeni operatorzy; nie odnotowano żadnych istotnych powikłań tego leczenia. Można było więc zaobserwować umiarkowany, korzystny, utrzymujący się po 3 miesiącach obserwacji wpływ denerwacji na obniżenie ciśnienia tętniczego, zwłaszcza rozkurczowego. Oczywiście badanie dotyczyło małej grupy i, co warto jeszcze raz podkreślić, nie obejmowało chorych ze zdiagnozowanym nadciśnieniem opornym, tylko nieleczonych pacjentów z potwierdzonym umiarkowanym nadciśnieniem tętniczym. Wydaje się zatem, że koncepcja denerwacji dzięki ulepszonym wielopunktowym cewnikom ablacyjnym nie odeszła całkowicie do kardiologicznego „lamusa”, jednak opisane wyniki nie pozwalają określić jej praktycznej użyteczności czy też pozycji wśród współczesnych strategii prewencji.

\section{Piśmiennictwo}

1. Escaned J, Collet C, Ryan N, et al. Clinical outcomes of state-of-the-art percutaneous coronary revascularization in patients with de novo three vessel disease: 1-year results of the SYNTAX II study. Eur Heart J. 2017; 38(42): 3124-3134, doi: 10.1093/eurheartj/ehx512, indexed in Pubmed: 29020367.

2. Marrouche NF, Brachmann J, on behalf of CASTLE-AF Investigators. Catheter ablation versus standard conventional treatment in patients with left ventricular dysfunction and atrial fibrillation: The CASTLE-AF trial. European Society of Cardiology 2017 Congress. August 27, 2017, Barcelona, Spain.

3. Ezekowitz MD, Pollack CV, Sanders P, et al. Apixaban compared with parenteral heparin and/or vitamin $\mathrm{K}$ antagonist in patients with nonvalvular atrial fibrillation undergoing cardioversion: Rationale and design of the EMANATE trial. Am Heart J. 2016; 179: 59-68, doi: 10.1016/j.ahj.2016.06.008, indexed in Pubmed: 27595680.

4. Cannon CP, Bhatt DL, Oldgren J, et al. RE-DUAL PCI Steering Committee and Investigators. Dual antithrombotic therapy with dabigatran after PCl in atrial fibrillation. N Engl J Med. 2017; 377(16): 1513-1524, doi: 10.1056/NEJMoa1708454, indexed in Pubmed: 28844193.

5. Townsend RR, Mahfoud F, Kandzari D, et al. Catheter-based renal denervation in patients with uncontrolled hypertension in the absence of antihypertensive medications (SPYRAL HTN-OFF MED): a randomised, sham-controlled, proof-of-concept trial. Lancet. 2017; 390(10108): 2160-2170, doi: 10.1016/s0140-6736(17)32281-x, indexed in Pubmed: 28859944. 